\title{
Benign fibrous histiocytoma of bone: A case report
}

\author{
Nagarekha Kulkarni
}

\begin{abstract}
Introduction: Benign fibrous histiocytoma of bone is a rare tumor. Only few cases have been reported in literature. Case Report: A 45-yearold female presented with pain in the ankle. Radiological findings revealed osteolytic lesion of talus and histological features were similar to non-ossifying fibroma and metaphyseal fibrous defect. Because of pain, unusal location and unusual age group the lesion was diagnosed as benign fibrous histiocytoma of Talus. Conclusion: Benign fibrous histiocytoma should be considered as one of the histopathological diagnosis although benign fibrous histiocytoma of bone is a rare entity.
\end{abstract}

Keywords: Talus, Fibrous histiocytoma, Fibrohistiocytic

$* * * * * * * * *$

Kulkarni N. Benign fibrous histiocytoma of bone: A case report. International Journal of Case Reports and Images 2013;4(4):224-227.

$* * * * * * * * *$

Nagarekha Kulkarni ${ }^{1}$

Affiliations: ${ }^{1}$ Associate Professor, Department of Pathology, Vijayanagara Institute of Medical Sciences, Bellary, Karnataka, India.

Corresponding Author: Dr. Nagarekha Kulkarni, Associate Professor, Department of Pathology, Vijayanagara Institute of Medical Sciences, Bellary - 583104. Karnataka, India; Phone: 08392 - 257700; Mob: +919449463366

Received: 10 November 2012

Accepted: 07 December 2012

Published: 01 April 2013
doi:10.5348/ijcri-2013-04-299-CR-8

\section{INTRODUCTION}

The histogenesis and classification of fibrohistiocytic lesions that involve bones, are confusing and overlap several entities such as (a) metaphyseal fibrous defect, (b) non-ossifying fibroma, (c) fibrous cortical defect, (d) fibrous xanthoma and (e) benign fibrous histiocytoma [1]. Since the report by Stout and Lattes, benign or malignant histiocytic tumors arising in somatic soft tissues are becoming a well-established entity [2]. On the other hand, histiocytic tumors arising within the bone are still controversial and only recently have been recognized as a clinicopathologic entity. About 100 cases are reported in literature so far [3]. Patients have ranged in age from 6 to 74 years at diagnosis, $60 \%$ being older than age 20 years, with a slight female preponderance. Approximately, $40 \%$ of benign fibrous histiocytoma (BFH) occur in the long bones, with femur and tibia most frequently involved. As many as $25 \%$ of cases involve the pelvic bones, in particular the ilium. In the long bones, $\mathrm{BFH}$ is centered in the epiphysis or diaphysis. In most (65\%) the lesion causes pain which may be present for days up to several years. Some patients (15\%) are asymptomatic. Occasional patients present because of pathological fracture [4]. Benign fibrous histiocytoma bone composed of spindle-shaped fibroblasts, arranged in a storiform pattern, with a variable admixture of small, multinucleated osteoclastlike giant cells. Foamy cells (xanthoma), chronic inflammatory cells, stromal hemorrhages and hemosiderin pigment are also present. The giant cells in $\mathrm{BFH}$ tend to have fewer nuclei than those found in osteoclastoma or giant cell tumor.The microscopic features were similar to metaphyseal fibrous defect seen in young children less than 5 years and second lesion is non-ossifying fibroma seen in older children between 10-15 years [5]. Both are quite benign, self limiting and self healing unless accompanied by pathological fractures. 
Herein, a case report of benign fibrous histiocytoma of talus in an elderly patient presenting with ankle pain is discussed.

\section{CASE REPORT}

A 45-year-old female was admitted to the Medical College Hospital with complaints of pain in the right ankle since 6 years. On examination tenderness was present over the lateral aspect of right ankle. Plantar flexion was restricted. There was no distal neurological or vascular deficit and the regional lymphnodes were not palpable. X-ray findings of right talus showed a lytic, loculated appearance with prominent sclerosis of the edges of the lesion. There was no matrix mineralization. The zone of transition of the lesion was narrow (Figure 1). Clinical diagnosis of osteoclastoma was made. Currettage and bone grafting were done. Currettage was sent for histopathological examination. The currettage was processed routinely. Hematoxylin and Eosin stained sections showed spindle cells arranged in storiform pattern with involvement of bone at the foci. The cells had elongated bland nuclei, moderate to abundant cytoplasm and indistinct cell margins. No pleomorphism and atypical mitotic figures were found. Scattered foamy histiocytes along with occasional foci of scattered osteoclast type of giant cells were found (Figures 2 and 3). The final diagnosis of benign fibrous histiocytoma was made. Patient's symptoms disappeared completely 10 days after operation. There was no evidence of recurrence after two year of postoperative follow-up.

\section{DISCUSSION}

Benign fibrous histiocytoma is a relatively common and well characterized soft tissue lesion. It occurs rarely in bone, approximating to $1 \%$ of all benign bone tumors. Many authors have used the term benign fibrous histiocytoma to describe a lesion that shares similar microscopic findings with the one in this case [3]. Benign fibrous histiocytoma is microscopically identical to metaphyseal fibrous defect, non-ossifying fibroma but benign fibrous histiocytoma is usually seen in older age group and have low reccurence rates [6].

There is no defined age group for this tumor except that patients are generally older than those found with a non-ossifying fibroma. Korhan et al., Zia et al. reported a case of 65 years and 32 years old female, respectively as in our case [7, 8]. It is usually found in long bones most commonly in the femur and tibia, but various authors reported $\mathrm{BFH}$ from pelvic, lumbar spine, rib [8]. Benign fibrous histiocytoma in the present case is unusually located in the talus. Most of the time tumor presents with pain at the site of lesion which is similar to our study. The diagnosis was based on X-ray findings, computed tomography (CT) scan, and magnetic resonance imaging (MRI) scan. In the present case only $\mathrm{X}$-ray was done which showed osteolytic lesion of the

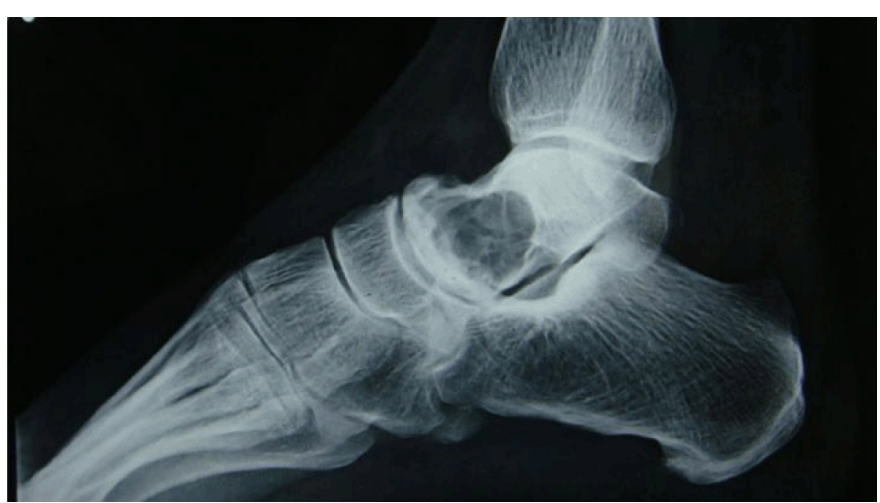

Figure 1: Preoperative X-ray shows osteolytic lesion of talus.

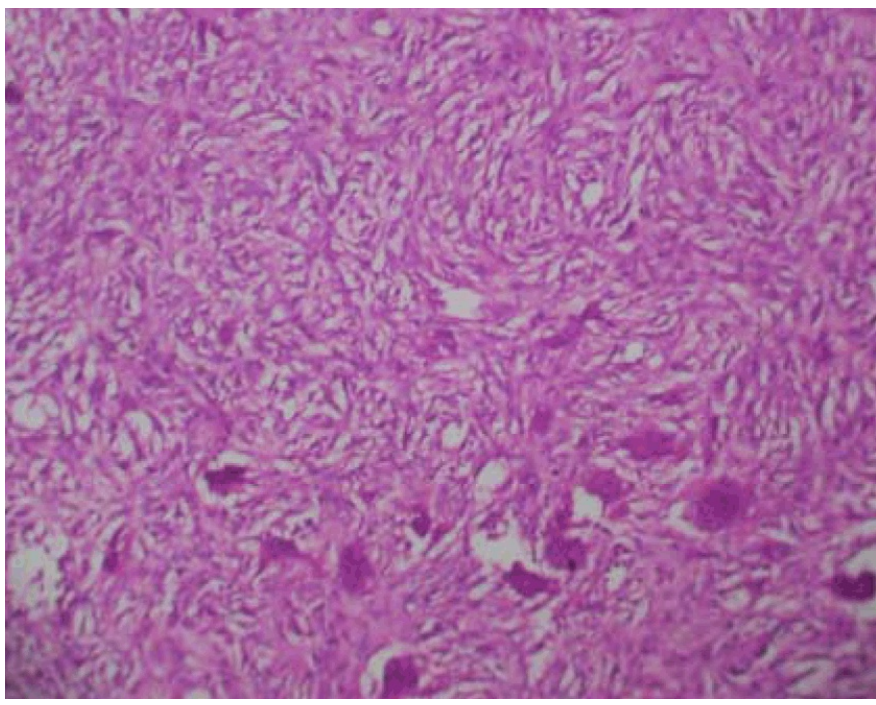

Figure 2: Sections show spindle cells arranged in storiform pattern with scattered histiocytes and multinucleated giant cells. (H\&E, x100)

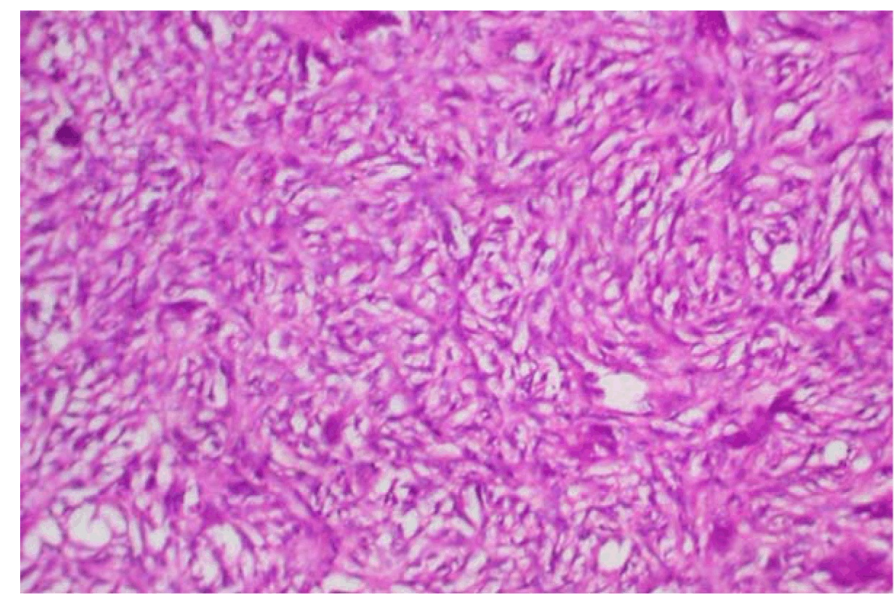

Figure 3: Sections show spindle cells arranged in storiform pattern with scattered histiocytes and multinucleated giant cells. (H\&E, X4OO).

talus. Benign fibrous histiocytoma should be differentiated from xanthoma of the bone, which radiologically resembles non-ossifying fibroma and 
osteoblastoma. Some consider these lesions as neoplastic processes under the broad category of $\mathrm{BFH}$,where as others consider primary xanthoma of bone as a separate entity[9].

Histological appearance of $\mathrm{BFH}$ of bone is characterized by proliferation of fibroblasts and histiocytes with many multinucleated giant cells. The fibroblasts are arranged in storiform pattern, the giant cells tend to have fewer nuclei than those found in osteoclastoma or giant cell tumor [10]. The histology of $\mathrm{BFH}$ of bone is similar to metaphyseal fibrous defect, non-ossifying fibroma [1].

These tumors can be locally aggressive and may recur after curettage [11]. Five out of eight patients had pain and three patients had recurrence and two patients had undergone amputation in Clarke's series [9]. Bertoni et al. reported seven cases out of these six patients had pain with no recurrence and no amputation [12]. In our patient there was no recurrence even after follow-up of two years.

\section{CONCLUSION}

In this case the diagnosis of benign fibrous histiocytoma of bone involving talus was based on age, pain at the site of lesion, radiological findings and histiological appearance. This case intends to remind that whenever an elderly patient presents with a painful bone tumor like lesion benign fibrous histiocytoma of bone should be considered as one of the histopathological diagnosis although benign fibrous histiocytoma of bone is a rare entity.

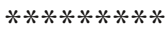

\section{Acknowledgements}

I thank Director, Prinicipal, Medical Superintendent, Professor \& Head of the Department of Pathology and Orthopaedics of VIMS, Bellary for their support \& encouragement to prepare this report.

\section{Author Contributions}

Nagarekha Kulkarni - Substantial contributions to conception and design, Acquisition of data, Analysis and interpretation of data, Drafting the article, Revising it critically for important intellectual content, Final approval of the version to be published

\section{Guarantor}

The corresponding author is the guarantor of submission.

\section{Conflict of Interest}

Authors declare no conflict of interest.

\section{Copyright}

(C) Nagarekha Kulkarni et al. 2013; This article is distributed under the terms of Creative Commons Attribution 3.0 License which permits unrestricted use, distribution and reproduction in any means provided the original authors and original publisher are properly credited. (Please see www.ijcasereportsandimages.com /copyright-policy.php for more information.)

\section{REFERENCES}

1. Sanatkumar S, Rajagopalan N, Mallikarjunaswamy B, Srinivasalu S, Sudhir NP, Usha K. Benign fibrous histiocytoma of the distal radius with congenital dislocation of the radial head: a case report. J Orthop Surg (Hong Cong) 2005;13(1):83-7.

2. Takeo Matsuno. Benign fibrous histiocytoma involving the ends of long bone. Skeletal Radiol 1990;19(8):561-6.

3. Grohs JG, Nicolakis M, Kainberger F, Lang S, Kotz R, Benign fibrous histiocytoma of bone: a report of ten cases and review of literature. Wien Klin Wochenschr 2002 Jan 15;114(1-2):56-3.

4. M. Kyriakos. IARC: Benign fibrous histiocytoma of bone.13 sep 2006.Available at www.iarc.fr/en/publications/pdfs-online/patgen/.../bb5-chap 13.pdf

5. Hermann G, Steiner GC, Sherry HH. Case report 465: Benign fibrous histiocytoma (BFH). Skeletal Radiol 1988;17(3):195-8.

6. Matsuno T. Benign fibrous histiocytoma involving the ends of long bones. Skeletal Radiol 1990;19(8):561-6.

7. Korhan Ozkan, Kerem Bilsel, Harzem Ozger, Feyza Unlu Ozkan, Zafer Coban. Benign fibrous histiocytoma of sacroiliac joint. Journal of orthopaedics 2006;3(1)e9.

8. Zia SA, Raza SH. Benign fibrous histiocytoma of the rib. J Pak Med Assoc 2001 Apr;51(4):162-3.

9. Clark BE, Xipell JM, Thomas DP. Benign fibrous histiocytoma of bone. Am J Surg Pathol 1985;9(11):806-15.

10. Azouz EM. Benign fibrous histiocytoma of the proximal tibial epiphysis in a 12 year old girl. Skeletal Radiol 1995 Jul;24(5):375-8.

11. Destouet JM, Kyriakos M, Gilula LA. Fibrous histiocytoma (fibroxanthoma) of a cervical vertebra. A report with a review of the literature. Skeletal Radiol 1980;5(4):241-6.

12. Bertoni F, Calderoni $\mathrm{P}$, Bacchini $\mathrm{P}$, et al. Benign fibrous histiocytoma of bone. J Bone Joint Surg Am 1986 Oct;68(8):1225-30. 
Access PDF of article on other devices

other devices

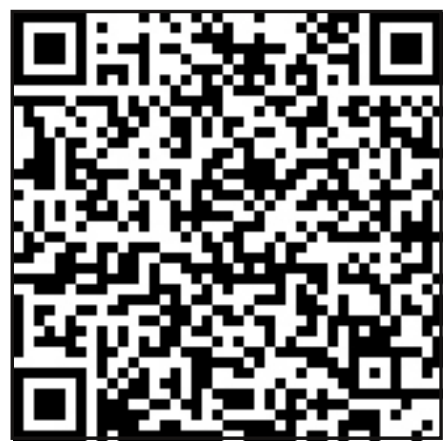

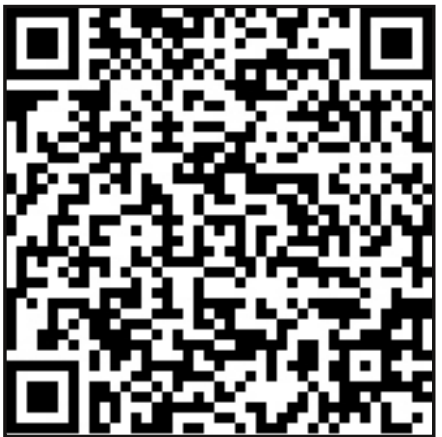

